\title{
REPRODUCTION OF Pratylenchus zeae AND P. brachyurus IN COVER CROPS ${ }^{1}$
}

\author{
SIMONE DE MELO SANTANA-GOMES ${ }^{2 *}$, CLAUDIA REGINA DIAS-ARIEIRA ${ }^{3}$, JÚLIO CÉSAR ANTUNES \\ FERREIRA $^{4}$, RAIANE PEREIRA SCHWENGBER ${ }^{3}$, SEPHORA SERRANO BALDISERA $^{5}$
}

\begin{abstract}
This study aimed to evaluate the reproduction of Pratylenchus zeae and P. brachyurus in leguminous plants used as cover crops. Seedlings of sunn hemp (Crotalaria juncea and C. spectabilis), pigeon pea cultivar IPR 43 (Cajanus cajan), dwarf velvet bean (Mucuna deeringiana), black velvet bean (Stizolobium aterrimum), and jack bean (Canavalia ensiformis) were inoculated with each nematode separately. Maize cultivar IPR 114 and soybean cultivar Pintado were used as controls to measure the viability of the inoculation of $P$. zeae and P. brachyurus. After 90 days of inoculation, the plants were collected and nematode $\mathrm{g}^{-1}$ root, final population, and reproduction factors (RF) were evaluated. The experiment was carried out at two different times of the year. The nematode's RF on cover crops from treatments with the two Crotalaria species, dwarf pigeon pea, and black velvet bean were lower than one (bad host plants) in both experiments for P. zeae. For $P$. brachyurus, the lowest RFs were obtained for C. juncea, $C$. spectabilis, and pigeon pea, while the other plants presented RF values close to or higher than one in at least one of the experiments. Therefore, C. spectabilis, $C$. juncea, and $C$. cajan cultivar IPR 43 are antagonistic plants that represent useful options for rotation or succession systems that aim to control $P$. zeae and $P$. brachyurus.
\end{abstract}

Keywords: Cover crops. Leguminous plants. Multiplication. Root lesion nematodes.

\section{REPRODUÇÃO DE Pratylenchus zeae E P. brachyurus EM PLANTAS DE COBERTURA}

RESUMO - O trabalho teve como objetivo avaliar a reprodução de Pratylenchus zeae e P. brachyurus em plantas leguminosas usadas como adubos verdes. Plântulas de crotalária (Crotalaria juncea e C. spectabilis), guandu cv. IPR 43 (Cajanus cajan), mucuna-anã (Mucuna deeringiana), mucuna-preta (Stizolobium aterrimum) e feijão-de-porco (Canavalia ensiformis) foram inoculadas com ambos nematoides separadamente. O milho cv. IPR 114 e a soja cv. Pintado foram utilizadas como testemunhas da viabilidade do inóculo de $P$. zeae e $P$. brachyurus. Após 90 dias da inoculação, as plantas foram coletadas avaliando-se nematoide $\mathrm{g}^{-1} \mathrm{de}$ raiz, população final e fator de reprodução (FR). O experimento foi conduzido em duas épocas distintas. Os FRs dos nematoides nas duas espécies de crotalárias, no guandu e na mucuna-preta foram menores que um em ambos os experimentos para $P$. zeae, comportando como más hospedeiras. Para P. brachyurus, os menores valores de FRs foram obtidos em $C$. juncea, C. spectabilis e guandu, enquanto nas demais leguminosas, os valores de FR foram próximos ou superiores a um em pelo menos um dos experimentos. Portanto, $C$. spectabilis, $C$. juncea e $C$. cajan cv. IPR 43 são opções de plantas antagonistas para sistemas de rotação ou sucessão que visem o controle de $P$. zeae e P. brachyurus.

Palavras-chave: Adubos verdes. Leguminosas. Multiplicação. Nematoide das lesões radiculares.

\footnotetext{
${ }^{*}$ Corresponding author

${ }^{1}$ Received for publication in $05 / 17 / 2017$; accepted in 11/14/2018.

Paper extracted from the doctoral thesis of the first author.

${ }^{2}$ Agricultural Sciences Post Graduation, Universidade Estadual de Maringa, Umuarama, PR, Brazil; sms.nema@gmail.com - ORCID: 0000 $-0003-4072-564 X$.

${ }^{3}$ Agronomy Post Graduation, Universidade Estadual de Maringá, Maringá, PR, Brazil; crdarieira@uem.br - ORCID: 0000-0002-1567816X, raiane_schwengber@hotmail.com - ORCID: 0000-0003-2979-4521.

${ }^{4}$ Agronomy Post Graduation, Universidade Estadual Júlio de Mesquita Filho, Botucatu, SP, Brazil; julio.cesar.antunes@hotmail.com ORCID: 0000-0002-3881-3846.

${ }^{5}$ Department Esthetics and Cosmetic Technology, Faculdade União de Campo Mourão, Campo Mourão, PR, Brazil; sephorabaldisera@gmail.com - ORCID: 0000-0002-7090-8239.
} 


\section{INTRODUCTION}

Root lesion nematodes are recognized worldwide as one of the greatest problems in crops of considerable economic importance, such as soybeans, maize, cotton, sugarcane, among others (KORAYEM; MOHAMMED, 2010; MACHADO; BONFIM JÚNIOR; ARAÚJO FILHO, 2010; ARAÚJO FILHO; CASTRO-MORETTI; BONFIM JÚNIOR, 2014). In Brazil, two species deserve attention due to their geographical distribution and the damage caused to agriculture, namely Pratylenchus zeae Graham and $P$. brachyurus (Godfrey) Filipjev and Schuurmans Steckhoven (SEVERINO; DIAS-ARIEIRA; TESSMANN, 2010; FRANCHINI et al., 2014).

Pratylenchus zeae has been detected in the main sugarcane producing regions of Brazil, usually in high population concentrations in commercial production areas of the state of São Paulo (NOVARETTI et al., 2014), Northeast region (MOURA et al., 2000), Paraná (SEVERINO; DIASARIEIRA; TESSMANN, 2010), and Rio Grande do Sul (BELLÉ et al., 2017). Alone, or in mixed populations with Meloidogyne spp., the pathogen causes average reductions of $20-30 \%$ in yield from the first cut of susceptible varieties (DINARDOMIRANDA, 2005), as well as losses of 10-20 $\mathrm{tha}^{-1}$ per cut and reductions in ratoon longevity (BARROS; MOURA; PEDROSA, 2005).

On the other hand, Pratylenchus brachyurus has become a major concern in areas planted with soybean, maize, sugarcane, and cotton (SEVERINO; DIAS-ARIEIRA; TESSMANN, 2010; INOMOTO, 2011; MACHADO; FERRAZ; INOMOTO, 2012; BELLÉ et al., 2017). In soybean crops, losses of 30$50 \%$ in production were recorded (DIAS; GARCIA; SILVA, 2010). According to Inomoto, Machado and Antedomênico (2007), problems arising from the infestation of this species were aggravated by the introduction of a no-tillage system that, despite its undeniable benefits, allowed the multiplication of the pathogen, favoring its survival and the maintenance of high populations during intercrop periods.

The management of both species is complex and requires the adoption of integrated measures. Planting leguminous species prior to the sugarcane crop may be an efficient method in an integrated phytonematode control system (DINARDOMIRANDA; FRACASSO, 2009).

Due to the scarcity of vegetable material resistant to root-lesion nematodes and limitations regarding the use of chemical control, crop rotation is becoming increasingly important. Thus, growing plants as green manure is crucial, as it increases soil coverage and the yield of subsequent crops (DEBIASI et al., 2016).

In a study with leguminous plants, Obici et al. (2011) observed that forage peanut (Arachis pintoi Krap and Greg.), pigs (Canavalia ensiformis (L.)
DC), and Stylosanthes Campo Grande (Stylosanthes capitata Vog. + S. macrocephala MB Ferreira and S. Costa) in soils infested with $P$. zeae, promoted the reduction of the parasite both in the antagonistic plant and in sugarcane grown as a subsequent crop. In another study, Santana et al. (2012) found that pigeon pea (Cajanus cajan (L.) Mill) and crotalaria (Crotalaria spectabilis Roth) effectively controlled P. zeae.

Regarding the management of $P$. brachyurus, studies have demonstrated the potential of some species of green manures such as $C$. spectabilis and C. ochroleuca L. However, these studies have also warned of a possible multiplication of $P$. brachyurus in $C$. juncea (MACHADO et al., 2007; RIBEIRO et al., 2007). The findings of studies on the efficiency in the control of the pathogen in black velvet bean, dwarf velvet bean, gray velvet bean, and pigeon pea differ (INOMOTO et al., 2006; MACHADO et al., 2007). Therefore, the present study aimed to evaluate the reproduction of $P$. zeae and $P$. brachyurus in leguminous species used as green manures.

\section{MATERIAL AND METHODS}

The experiments were conducted in a greenhouse at the Universidade Estadual de Maringá, Regional Campus of Umuarama, in two different periods. Each experiment was conducted in a completely randomized design with four replicates.

For $P$. zeae, experiment 1 was conducted from June to September 2012, under minimum and maximum temperatures of 16.1 and $26.8{ }^{\circ} \mathrm{C}$, respectively, while experiment 2 was conducted between November 2012 and February 2013, under minimum and maximum temperatures of 21.2 and $32.1{ }^{\circ} \mathrm{C}$, respectively. For P. brachyurus, experiment 1 was conducted between November 2012 and February 2013, under minimum and maximum temperatures of 22.1 and $31.2{ }^{\circ} \mathrm{C}$, respectively, while experiment 2 was performed in the same period of the $P$. zeae experiment.

The reproduction of $P$. zeae and $P$. brachyurus was measured in the species Crotalaria juncea L., C. spectabilis, pigeon pea cultivar IPR 43, dwarf velvet bean (Mucuna deeringiana (Bort) Merr.), black velvet bean (Stizolobium aterrimum Piper and Tracy), and jack bean (Canavalia ensiformis), using maize cultivar IPR 114 and soybean cultivar Pintado as controls. Initially, the seeds of the evaluated species were placed in polystyrene trays containing Plantmax ${ }^{\circledR}$ type substrate. Approximately 10 days after germination, the seedlings were transplanted into 2-liter vessels containing soil:sand (2:1, v: v), previously autoclaved at $121^{\circ} \mathrm{C}$ for 2 hours.

Three days after the transplant, the seedlings were inoculated with the respective nematodes. The inoculum of both nematodes was obtained from pure 
nematode populations and kept in greenhouse with maize. For the extraction of pathogens, the methodology of root nematode extraction proposed by Coolen and D'Herde (1972) was adopted. The obtained suspensions were calibrated for initial populations (Ip) of 2,100 and 3,000 P. zeae/plant specimens in the first and second experiments, respectively, and 2,300 $P$. brachyurus/plant specimens in both experiments.

After 90 days of inoculation, the plants were removed from the vases and the aerial part was discarded. The roots were collected, carefully washed, and placed on towel paper to remove excess moisture. Subsequently, root fresh mass was determined with a semi-analytical scale and the nematodes were extracted from the roots of each plant as previously described. The final population (Fp) of nematodes in the different experiments was then determined. Finally, the reproduction factor (RF $=$ Fp / Ip) was assessed as follows: plants with $\mathrm{RF} \geq$ 1 were considered susceptible (good hosts); plants with $\mathrm{RF}<1$ were considered resistant (bad hosts), and plants with $\mathrm{RF}=0$ (zero) were considered immune, according to the classification proposed by Oostenbrink (1966).

The data obtained in the different treatments were submitted to analysis of variance and the means were compared with the Scott-Knott test at 5\% probability. The statistical software SISVAR was used for all analyses (FERREIRA, 2008). The means were transformed by $\sqrt{x+1}$ for the analysis.

\section{RESULTS AND DISCUSSION}

In experiment $1, P$. zeae did not reproduce in any of the plants assessed, as it can be seen in the number of nematodes per $\mathrm{g}^{-1}$ of root, final nematode population, and RF (Table 1). On the other hand, maize (used as control) had $\mathrm{RF}=11.6$, confirming the viability of the inoculum. In experiment $2, P$. zeae showed high values of RF in maize (36.6) and, although dwarf velvet bean and jack bean showed a susceptible behavior, RF values were lower and the other green manures were resistant or immune.

Table 1. Number of nematodes per $\mathrm{g}^{-1}$ of root, final population, and reproduction factor (RF) of Pratylenchus zeae in different plants used as green manures after 90 days of inoculation.

\begin{tabular}{|c|c|c|c|}
\hline Treatment & Nematodes per $\mathrm{g}^{-1}$ of root & Final population & RF \\
\hline \multicolumn{4}{|c|}{ Experiment 1} \\
\hline Maize* & $711 \mathrm{a}$ & $24316 \mathrm{a}$ & 11.6 \\
\hline Crotalaria juncea & $0 \mathrm{~b}$ & $0 \mathrm{~b}$ & 0 \\
\hline Crotalaria spectabilis & $0 \mathrm{~b}$ & $0 \mathrm{~b}$ & 0 \\
\hline Pigeon pea & $0 \mathrm{~b}$ & $0 \mathrm{~b}$ & 0 \\
\hline Dwarf velvet bean & $0 \mathrm{~b}$ & $0 \mathrm{~b}$ & 0 \\
\hline Black velvet bean & $0 \mathrm{~b}$ & $0 \mathrm{~b}$ & 0 \\
\hline Jack bean & $0 \mathrm{~b}$ & $0 \mathrm{~b}$ & 0 \\
\hline $\mathrm{CV}(\%)$ & 17.28 & 12.31 & \\
\hline \multicolumn{4}{|c|}{ Experiment 2} \\
\hline Maize* & $2928 \mathrm{a}$ & $109800 \mathrm{a}$ & 36.6 \\
\hline Crotalaria juncea & $20 \mathrm{c}$ & $596 \mathrm{c}$ & 0.2 \\
\hline Crotalaria spectabilis & $0 \mathrm{c}$ & $0 \mathrm{c}$ & 0 \\
\hline Pigeon pea & $0 \mathrm{c}$ & $0 \mathrm{c}$ & 0 \\
\hline Dwarf velvet bean & $211 b$ & $6098 \mathrm{~b}$ & 2.0 \\
\hline Black velvet bean & $8 \mathrm{c}$ & $268 \mathrm{c}$ & 0.1 \\
\hline Jack bean & $228 \mathrm{~b}$ & $4788 \mathrm{~b}$ & 1.6 \\
\hline $\mathrm{CV}(\%)$ & 25.63 & 36.85 & - \\
\hline
\end{tabular}

Means followed by the same letter in the columns do not differ by the Scott-Knott test at $5 \%$ probability. CV = coefficient of variation. $\mathrm{RF}=$ Final population $(\mathrm{Fp}) /$ initial population (Ip) (OOSTENBRINK, 1966). Original means transformed by $\sqrt{x+1}$, for statistical analysis. *Susceptible control.

The two species of Crotalaria in the study effectively reduced $P$. zeae populations, according to the RF value observed in $C$. juncea in experiment 2 (Table 2). The cultivation of $C$. spectabilis also reduced this species in the study conducted by Santana et al. (2012), with RF values ranging from 0.01 to 0.15 after 60 and 110 days of cultivation in naturally infested soil, respectively. In another study, Santana-Gomes et al. (2016) found a reduced penetration rate of $P$. zeae in the roots of $C$. spectabilis when compared to those of maize inoculated with the same soil pathogen. Oliveira et al. (2008) found that the rotational system of caneCrotalaria-cane, adopted in soils infested with a mixed population of $P$. zeae and $P$. brachyurus, reduced the populations of the pathogen by up to $48 \%$, maintaining them at relatively lower levels for extended periods when compared to other evaluated systems. In other studies, $C$. juncea also allowed the control of $P$. zeae in sugarcane when grown in 
succession systems with black velvet bean, reducing the entire nematode population and increasing yield by $10.77-22.06 \%$ compared to fallow (MOURA et al., 2010). In addition, even when grown alone, this plant showed superior results for the control of $P$. zeae in sugarcane (SUNDARARAJ; MEHTA, 1990).

In addition to the management of $P$. zeae, rotation of sugarcane with Crotalaria has other benefits, such as the control of root-knot nematodes (INOMOTO et al., 2006; MIAMOTO et al., 2016), which, as well as $P$. zeae, limit crop yield. Moreover, the efficiency in biological nitrogen fixation (BNF), reaching $450 \mathrm{~kg} \mathrm{~N} \mathrm{ha}^{-1}$ year $^{-1}$, of this leguminous plant produces approximately $30 \mathrm{t} \mathrm{ha}^{-1}$ of green manure phytomass (WUTKE, 1993). Ambrosano et al. (2010) also reported an increase in sugar production of around $35 \%$ with the use of $C$. juncea in rotation with sugarcane.

The efficiency of pigeon pea in the control of $P$. zeae corroborates the results obtained by Santana et al. (2012), who demonstrated that, regardless of the type of naturally infested soil (clayey or sandy), the species effectively reduced the levels of this pathogen in soils. Furthermore, the resistance of different pigeon pea varieties to $P$. zeae was confirmed in other studies (ARAÚJO FILHO et al., 2010; SOUTO; GODOY; INOMOTO, 2011).

Black velvet bean was found to be more efficient in $P$. zeae control than the dwarf velvet bean, as it can be seen in the low values of RF obtained in both experiments. However, several studies have shown that this culture may react in different ways. Santana et al. (2012) found that, although the $P$. zeae population was lower in maize after the leguminous plant was grown in clayey soils, nematode reproduction was detected with RF values ranging from 1.76 to 16.69 after 60 and 110 days of cultivation, respectively. On the other hand, the same authors observed small variations in RF values in sandy soils (1.54-0). In another study, the cultivation of velvet bean for three months, followed by Crotalaria for another three months, and the reverse treatment, reduced the reproduction rates of $P$. zeae by $100 \%$ in naturally infested areas (MOURA; OLIVEIRA, 2009).

Although jack bean (Canavalia ensiformis) allowed the multiplication of $P$. zeae in one of the experiments of the present study, in other studies this crop effectively controlled the population of the pathogen in naturally infested soils of areas of sugar cane cultivation. Moreover, in addition to promoting the direct reduction of RF, it maintained low population levels of the pathogen in subsequent sugarcane crops (OBICI et al., 2011). This species also effectively reduced the population of $P$. zeae in the same crop (ARIM et al., 2006), with low penetration of the nematode when compared to maize (SANTANA-GOMES et al., 2016). In the present study, a higher reproduction of $P$. zeae was observed in experiment 2, when the average temperature was higher. This is an indication that the plant shows susceptibility to the nematode especially under conditions that are favorable to the parasite, possibly because the reproduction of this pathogen is favored by temperatures near $30{ }^{\circ} \mathrm{C}$ (ACOSTA; MALEK, 1979).

Regarding P. brachyurus, except for dwarf velvet bean, which in experiment 1 was infested by a total nematode population equal to that of soybean, reproduction in all leguminous plants was lower than that in the control treatment (Table 2). Crotalaria juncea, $C$. spectabilis, and pigeon pea behaved like bad hosts for the pathogen in both experiments, unlike jack bean that proved to be a good host in both experiments. For the leguminous plants dwarf velvet bean and black velvet bean, there was no repetition of RF values, that is, they behaved as good hosts in experiment 1 and bad hosts in experiment 2 .

The results obtained for Crotalaria (Table 2) are consistent with studies previously published by Machado et al. (2007) and Ribeiro et al. (2007), who found lower RF values of $P$. brachyurus in $C$. spectabilis than in $C$. juncea, although both crops behaved as bad hosts. Similar results were obtained by Inomoto et al. (2006), whose RF of P. brachyurus in $C$. spectabilis was 0.16 after 63 days of cultivation, and thus concluded that the crop was a bad host for the pathogen. Moreover, in other studies, growing $C$. spectabilis prior to soybean reduced the populations of $P$. brachyurus under greenhouse conditions (SANTANA-GOMES et al., 2014) and in the field (DEBIASI et al., 2016).

Pigeon pea (Cajanus cajan), which was a bad host crop for $P$. brachyurus, also reduced the population of this nematode (incorporated or not to the soil) in a study conducted by Vedoveto et al. (2013). In a study conducted by Inomoto et al. (2006), under greenhouse conditions in Piracicaba, São Paulo, the pigeon pea crop reduced the population of the pathogen, and the incorporation of this crop to the soil contributed to the control of $P$. brachyurus in experiments conducted by Sharma, Pereira and Resck (1982). However, research results are variable, for example, Machado et al. (2007) reported that the control of $P$. brachyurus by pigeon pea may vary depending on the origin of the nematode population and the cultivar of the crop. In this regard, Inomoto et al. (2006) observed that cultivar Fava Larga was susceptible to P. brachyurus $(\mathrm{RF}=1.57)$, while pigeon pea cultivar IPR 43 was resistant to the pathogen $(\mathrm{RF}=0.68)$. 
Table 2. Number of nematodes per $\mathrm{g}^{-1}$ of root and reproduction factor (RF) of Pratylenchus brachyurus in different plants used as green manures after 90 days of inoculation.

\begin{tabular}{lccc}
\hline \multicolumn{1}{c}{ Treatment } & Nematodes per g-1 of root & Final population & RF \\
\hline \multicolumn{1}{c}{ Experiment 1} & & 8.7 \\
\hline Soybean* & $1106 \mathrm{a}$ & $20019 \mathrm{a}$ & 0.6 \\
Crotalaria juncea & $231 \mathrm{~b}$ & $1317 \mathrm{~b}$ & 0.0 \\
Crotalaria spectabilis & $212 \mathrm{~b}$ & $106 \mathrm{~b}$ & 0.0 \\
Pigeon pea & $0 \mathrm{c}$ & $0 \mathrm{~b}$ & 3.2 \\
Dwarf velvet bean & $508 \mathrm{~b}$ & $7315 \mathrm{a}$ & 1.0 \\
Black velvet bean & $135 \mathrm{~b}$ & $2282 \mathrm{~b}$ & 1.1 \\
Jack bean & $162 \mathrm{~b}$ & $2446 \mathrm{~b}$ & - \\
\hline CV (\%) & 43.10 & 62.95 & 11.9 \\
\hline & \multicolumn{2}{c}{ Experiment 2 } & 0.6 \\
\hline Soybean* & $2632 \mathrm{a}$ & $27373 \mathrm{a}$ & 0.3 \\
Crotalaria juncea & $224 \mathrm{~b}$ & $1389 \mathrm{c}$ & 0.6 \\
Crotalaria spectabilis & $110 \mathrm{~b}$ & $649 \mathrm{c}$ & 0.8 \\
Pigeon pea & $112 \mathrm{~b}$ & $1456 \mathrm{c}$ & 0.0 \\
Dwarf velvet bean & $200 \mathrm{~b}$ & $0 \mathrm{c}$ & 2.4 \\
Black velvet bean & $0 \mathrm{~b}$ & $5534 \mathrm{~b}$ & - \\
Pigeon pea & $357 \mathrm{~b}$ & 45.98 & \\
\hline CV (\%) & 39.53 & & \\
\hline
\end{tabular}

Means followed by the same letter in the column do not differ by the Scott-Knott test at $5 \%$ probability. CV = coefficient of variation. $\mathrm{RF}=$ Final population in antagonistic plants $(\mathrm{Fp}) /$ initial population (Ip) (OOSTENBRINK, 1966). Original means transformed by $\sqrt{x+1}$, for statistical analysis. * Susceptible control.

Black velvet bean was more effective in limit $P$. brachyurus reproduction than dwarf velvet bean. Thus, the selection of appropriate species is crucial. In a study conducted by Vedoveto et al. (2013), black velvet bean also reduced the population of $P$. brachyurus, either incorporated or not, to the soil. Sharma, Pereira and Resck (1982) reported a decrease in the population of $P$. brachyurus and an increase in the yield of soybeans grown in succession to black velvet bean. Inomoto et al. (2006) also observed the susceptibility of velvet bean to $P$. brachyurus, with RF values of 14.35 and 8.73 for black velvet bean and gray velvet bean, respectively, after 63 days of inoculation. Machado et al. (2007) confirmed these results when they reported the multiplication of different populations of $P$. brachyurus in velvet bean. In addition to the aforementioned factors, Araújo Filho et al. (2010) cited other aspects that contribute to different results in studies involving nematodes, such as temperature and the total period of the experiment.

Although jack bean was found to be susceptible to $P$. brachyurus in both experiments, the population found in the roots was statistically lower than that of the control treatment. The multiplication of the parasite in jack bean roots was at least five times lower than that observed in soybean. The effectiveness of jack bean in the management of $P$. zeae had already been tested by Obici et al. (2011) and Arim et al. (2006). However, few studies were conducted on the effectiveness of this leguminous plant on P. brachyurus populations. In this aspect, Cassimiro et al. (2007) found that the population levels of $P$. brachyurus 90 days after planting in soil cultivated with jack bean were lower compared to six other treatments (fallow, pineapple, $C$. juncea, dwarf pigeon, black velvet bean, and marigold). Similar results were obtained by Sharma, Pereira and Resck (1982), who reported a significant reduction of $P$. brachyurus in the soil when cultivated with jack bean.

Dwarf velvet bean was found to be susceptible to P. brachyurus, with an RF value of 3.2, corroborating Motta et al. (2005), who found an RF of 1.24 after 68 days of inoculation of the plant with the pathogen. However, Sharma, Pereira and Resck (1982) reported that, under low infestation of $M$. javanica and $P$. brachyurus, black velvet bean or dwarf velvet bean effectively reduced the populations of these pathogens and contributed to the increase in the yield of subsequent soybean crops.

\section{CONCLUSIONS}

The species C. spectabilis, C. juncea, and Cajanus cajan IPR 43 are examples of antagonistic plants for $P$. zeae and P. brachyurus that can be used in systems of rotation or succession of crops in infested areas.

\section{REFERENCES}

ACOSTA, N.; MALEK., R. B. Influence of temperature on population development of eight species of Pratylenchus on soybean. Journal of Nematology, v. 11, n. 3, p. 229-231, 1979.

AMBROSANO, E. J. et al. Crop rotation biomass 
and arbuscular mycorrhizal fungi effects on sugarcane yield. Scientia Agricola, v. 67, n. 4, p. $692-701,2010$.

ARAÚJO FILHO, J. V. et al. Reação de linhagens de feijão guandu a Rotylenchulus reniformis $\mathrm{e}$ Pratylenchus zeae. Nematologia Brasileira, v. 34, n. 4, p. 204-210, 2010 .

ARAÚJO FILHO, J.; CASTRO-MORETTI, F.; BONFIM JUNIOR, M. Pratylenchus brachyurus (Nematoda: Pratylenchidae) in Guariroba in the state of Goiás, Brazil. Helminthologia, v. 51, n. 4. p. 352354, 2014.

ARIM, O. J. et al. Effects of Canavalia ensiformis and Mucuna pruriens intercrops on Pratylenchus zeae damage and yield of maize in subsistence agriculture. Plant Soil, v. 284, n. 1, p. 243-251, 2006.

BARROS, A. C. B.; MOURA, R. M.; PEDROSA, E. M. R. Estudo de interação variedade-nematicida em cana-de-açúcar, em solo naturalmente infestado por Meloidogyne incognita, M. javanica e Pratylenchus zeae. Nematologia Brasileira, v. 29, n. 1, p. 39-46, 2005.

BELLÉ, C. et al. Reproduction of Pratylenchus zeae on weeds. Planta Daninha, v. 35, n. 2, p. 1-8, 2017.

CASSIMIRO, C. M. et al. Plantas antagônicas e alqueive sobre a dinâmica populacional de nematoides no solo e na rizosfera do abacaxizeiro cv. Pérola. Tecnologia \& Ciência Agropecuária, v. 1, n. 1, p. 43-50, 2007.

COOLEN, W. A.; D'HERDE, C. J. Method for the quantitative extraction of nematodes from plant tissue. 1. ed. Ghent, BEL: State Nematology and Entomology Research Station, 1972. 77 p.

DEBIASI, H. et al. Práticas culturais na entressafra da soja para o controle de Pratylenchus brachyurus. Pesquisa Agropecuária Brasileira, v. 51, n. 10, p. 1720-1728, 2016.

DIAS, W. P.; GARCIA, A.; SILVA, J. F. V. Nematoides em soja: identificação e controle. Londrina, PR: Embrapa Soja, 2010. 8 p. (Circular Técnica, 76).

DINARDO-MIRANDA, L. L. Manejo de nematóides em cana-de-açúcar. Jornal Cana, v. 141, n. 9 , p. 64-69, 2005.

DINARDO-MIRANDA, L. L.; FRACASSO, J. V. Spatial distribution of plant-parasitic nematodes in sugarcane fields. Scientia Agricola, v. 66, n. 2, p. $188-194,2009$.
FERREIRA, D. F. SISVAR. Um programa para análises e ensino de estatística. Revista Symposium, v. 6, n. 1, p. 36-41, 2008.

FRANCHINI, J. C. et al. Perda de produtividade da soja em área infestada por nematoide das lesões radiculares na região médio norte do Mato Grosso. Agricultura de Precisão, v. 24, n. 2, p. 274-278, 2014

INOMOTO, M. M. Avaliação da resistência de 12 híbridos de milho a Pratylenchus brachyurus. Tropical Plant Pathology, v. 36, n. 5, p. 308-312, 2011.

INOMOTO, M. M. et al. Reação de seis adubos verdes a Meloidogyne javanica e Pratylenchus brachyurus. Nematologia Brasileira, v. 30, n. 1, p. 39-44, 2006.

INOMOTO, M. M.; MACHADO, A. C. Z.; ANTEDOMÊNICO, S. R. Reação de Brachiaria spp. e Panicum maximum a Pratylenchus brachyurus. Fitopatologia Brasileira, v. 32, n. 4, p. 341-344, 2007.

KORAYEM, A. M.; MOHAMMED, M. M. M. High yielding hybrid maize cultivar tolerant to Pratylenchus zea in Egypt. Pakistan Journal of Nematology, v. 1, n. 1, p. 109-114, 2010.

MACHADO, A. C. Z.; BONFIM JÚNIOR., M. F.; ARAÚJO FILHO, J. V. Pequi is a host for Pratylenchus zeae in the brazilian cerrado region. Plant Disease, v. 94, n. 6, p. 790, 2010

MACHADO, A. C. Z.; FERRAZ, L. C. C. B.; INOMOTO, M. M. Pathogenicity of Pratylenchus brachyurus on cotton plants. Journal of Cotton Science, v. 16, n. 4, p. 268-271, 2012.

MACHADO, A. C. Z. et al. Host status of green manures for two isolates of Pratylenchus brachyurus in Brazil. Nematology, v. 9, n. 6, p. 799-805, 2007.

MIAMOTO, A. et al. Penetration and Reproduction of Meloidogyne javanica on leguminous crops. Journal of Phytopathology, v. 164, n. 11, p. 890895,2016

MOTTA, L. C. C. et al. Opções de adubos verdes para utilização em algodoais infestados por Pratylenchus brachyurus. In: CONGRESSO BRASILEIRO DE ALGODÃO, $\mathrm{n}^{\circ}$ 5., 2005, Salvador. Anais... Salvador, 2005. 5 p

MOURA, R. M.; OLIVEIRA, I. S. Controle populacional de Pratylenchus zeae em cana-deaçúcar em dois ambientes edáficos no nordeste do Brasil. Nematologia Brasileira, v. 33, n. 12, p. $67-$ 
73, 2009.

MOURA, R. M. et al. Ocorrência dos nematóides Pratylenchus zeae e Meloidogyne spp. em cana-deaçúcar no Nordeste do Brasil. Fitopatologia Brasileira, v. 25, n. 1, p. 101-103, 2000.

MOURA, R. M. et al. Efeito de adubos verdes na densidade de Pratylenchus zeae e na produtividade da cana-de-açúcar. Nematologia Brasileira, v. 34, n. 2, p. 132-136, 2010.

NOVARETTI, W. R. T. et al. Interaction between the nematicide nimitz and herbicides used in sugarcane production and Pratylenchus zeae. Journal of Nematology, v. 46, n. 1, p. 213-213, 2014.

OBICI, L. V. et al. Effect of leguminous plants on Pratylenchus zeae and Helicotylenchus dihystera in naturally infested soils. Nematropica, v. 41, n. 2, p. 215-222, 2011.

OLIVEIRA, F. S. et al. Efeito de sistemas de cultivo no manejo de populações de Pratylenchus spp. na cultura da cana-de-açúcar. Nematologia Brasileira, v. 32, n. 2, p. 117-125, 2008.

OOSTENBRINK, R. Major characteristics of the relation between nematodes and plants. Mededeelingen der Landbouw-Hoogeschool, v. 66, n. 3, p. 1-46, 1966.

RIBEIRO, N. R. et al. Avaliação da reação de espécies vegetais ao nematoide das lesões radiculares. In: REUNIÃO DE PESQUISA DE SOJA DA REGIÃO CENTRAL DO BRASIL, 28., 2006, Uberaba. Anais... Campo Grande: Uniderp, 2007. p. 64-65.

SANTANA, S. M. et al. Manejo de Pratylenchus zeae por plantas antagonistas, em solos de áreas de cultivo de cana-de-açúcar. Nematropica, v. 42, n. 1, p. 63-71, 2012.

SANTANA-GOMES, S. M. et al. Crop succession in the control of Pratylenchus brachyurus in soybean. Nematropica, v. 44, n. 2, p. 200-206, 2014.

SANTANA-GOMES, S. M. et al. Penetration of Pratylenchus zeae in antagonistic plants. Nematology, v. 18, n. 7, p. 1-3, 2016.

SEVERINO, J. J.; DIAS-ARIEIRA, C. R.; TESSMANN, D. J. Nematodes associated with sugarcana (Saccharum spp.) in sandy soils in Parana, Brazil. Nematropica, v. 40, n. 1, p. 111-119, 2010.
SHARMA, R. D.; PEREIRA, J.; RESCK, D. V. S. Eficiência de adubos verdes no controle de nematoides associados a soja nos cerrados. 1. ed. Planaltina, DF: Embrapa Cpac, 1982. 30 p.

SOUTO, T. G.; GODOY, R.; INOMOTO, M. M. Lista adicional de linhagens de guandu resistentes a Pratylenchus zeae. Nematologia Brasileira, v. 35, n. $3-4$, p. $78-81,2011$.

SUNDARARAJ, P.; MEHTA, U. K. Host status of some economic crops to Pratylenchus zeae and their influence on subsequent sugarcane crops. Indian Journal of Nematology, v. 20, n. 2, p. 165-169, 1990.

VEDOVETO, M. V. V. et al. Adubos verdes no manejo de Pratylenchus brachyurus em soja. Nematropica, v. 43, n. 2, p. 226-232, 2013.

WUTKE, E. B. Adubação verde: manejo da fitomassa e espécies utilizadas no Estado de São Paulo. In: WUTKE, E. B.; BULISANI, E. A.; MASCARENHAS, H. A. A. (Eds.). CURSO SOBRE ADUBAÇÃO VERDE NO INSTITUTO AGRONÔMICO, 1，1993, Campinas: Instituto Agronômico, 1993. p. 17-29. (Documentos IAC, 35). 